Original Article

\title{
NEW FLAVONOID COMPOUND FROM ALLIUM HOOKERI THWAITES AS A GASTROPROTECTIVE AGENT
}

\author{
KHUMANTHEM DEEPAK SINGH*a, DIPAK CHETIA ${ }^{\mathrm{a}}$, BIPLAB D. E.
}

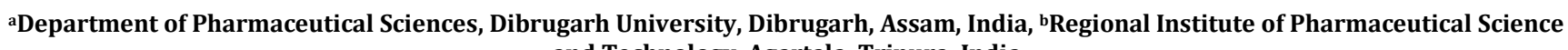
and Technology, Agartala, Tripura, India

Email: kh.deepaks@gmail.com

Received: 18 Dec 2017 Revised and Accepted: 22 Mar 2018

ABSTRACT

Objective: The main objective of this study was to investigate the antiulcer potential of an isolated flavonoid compound from Allium hookeri (AH).

Methods: Oral administration of ethanol-induced ulcer to the mucosal layer of the stomach in the rats. The ulcer score and percentage protection was calculated from the stomach and gastric mucosal scrapping was carried out for the biochemical studies. Antioxidant study was carried out in liver and histopathological study of the ulcer stomach was performed.

Results: Phytochemical investigation of methanolic extract of AH (MEAH) leaves afforded a new flavonoid compound characterized as 3, 5, 6trihydroxy-2-(4-hydroxy-3-(6-hydroxy-4, 5, 6, 7-tetrahydro benzofuran-7-yl) phenyl-7-methoxy-4H-chromen-4-one (Compound 1). The flavonoid compound at the dose of $5 \mathrm{mg} / \mathrm{kg}$ showed a significant change in ulcer index by reducing the ulcer index and increased in percentage protection. It also increased the in vivo antioxidant activity by increasing the superoxide dismutase (SOD), glutathione (GLU) and catalase (CAT) levels. The isolated compound reversed the increase of mucin content in the mucosal scrapings. The histopathology study showed the reversed of normal gland texture in the mucous layer of the standard and compound 1 treated stomach when compared to the negative control.

Conclusion: Present findings demonstrated the significant antiulcer activity and antioxidant activity of the isolated flavonoid compound as the supporting factor.

Keywords: Allium hookeri, Antiulcer, Isolated flavonoid, In vivo antioxidant

(C) 2018 The Authors. Published by Innovare Academic Sciences Pvt Ltd. This is an open access article under the CC BY license (http://creativecommons.org/licenses/by/4.0/] DOI: http://dx.doi.org/10.22159/ijpps.2018v10i5.24341

\section{INTRODUCTION}

Peptic ulcers occur when there is imbalance between offensive and defensive factors [1]. Such factors could range from natural causes (gastric cancer), infections (H. pylori), and lifestyle (drugs-Non steroidal anti-inflammatory drugs, alcohol, stress and cigarette smoking) [2,3]. Ulceration in the mucosa can be because of either breakdown of mucosa with the development of surface defects or failure of restitution of mucosal integrity resulting in retardation or failure of healing of the ulcers. No apparent causal factor is sufficiently uniquely associated with peptic ulcers to warrant unequivocal implication in pathogenesis of the ulceration. Although a number of antiulcer drugs such as $\mathrm{H}_{2}$ receptor antagonists, proton pump inhibitors and cytoprotectants are available for ulceration. All these drugs have side effects and limitations [4].

A current treatment of ulcers in developing countries has been largely suppression of pain with little or no strategy aimed at a cure. Herbal medicine is fast emerging as an alternative treatment to available synthetic drugs for the treatment of ulcer possibly due to lower cost, availability, fewer adverse effects and perceived effectiveness [5].

Allium hookeri Thw. Enum (Family: Liliaceae) is locally known as "Maroi napakpi." It is a herb with thick evergreen, linear with prominent midribs, basal leaves membranous, and shorter than the tall subtrigonous scape [6]. AH is widely used by the local people of Manipur, a North Eastern State of India to garnish cooking and as ingredients in cooking popular delicious dishes. The leaves of this plant has been used as a home remedy by the Meitei community of Manipur in their folklore medicine as an antiulcer agent [7], cardioprotective agent [8] and commonly available in the vegetable markets. Methanolic extract of Allium hookeri (MEAH) reduced the serum glucose level both in normal and streptozotocin-induced diabetic rats [9], and showing a preventive effect against peptic ulcer in rats [10]. The present study was designed to evaluate the antiulcer activity of the isolated compounds from the methanol fraction of $\mathrm{AH}$.

\section{MATERIALS AND METHODS}

\section{Chemicals and reagents}

Petroleum ether, methanol, ethyl acetate, phenolphthalein, acetyl acetone, sodium hydroxide, glacial acetic acid, phenazine methosulphate (PMS), nitro blue tetrazolium (NBT), nicotinamide adenine dinucleotide (NADH), ethanol, n-butanol, ethylenediaminetetraacetic acid (EDTA), trichloroacetic acid (TCA), tris buffer, 5,5'-dithios-(2-nitrobenzoic acid) DTNB, hydrogen peroxide, picric acid, formaldehyde were purchased from Merck India, Mumbai. Orcinol reagent, carboxymethyl cellulose (CMC), ehrlich reagent, sulphuric acid, cysteine reagent, topfer's reagent, sodium arsenite, thiobarbituric acid, cyclohexanone, sialic acid, oxalic acid, phenol, bovine albumin, sodium pyrophosphate buffer, paraffin wax were obtained from Hi-media Pvt. Ltd, Mumbai. Haematoxylin and eosin from nice chemicals, Cochin. Omeprazole was purchased from Micro Labs, Bangalore. All the chemicals and reagents used were of analytical grade.

\section{Instruments}

Melting points were determined on a Veego-MPI melting point apparatus without correction. The IR spectra were measured on an FT-IR Perkin-Elmer spectrometer without $\mathrm{KBr}$ pellet. Ultraviolet (UV) spectra were obtained on an UV-visible spectrophotometer (Shimadzu UV-1800). The ${ }^{1} \mathrm{H}$ and ${ }^{13} \mathrm{C}$ NMR spectra were recorded at $400 \mathrm{MHz}$ and $100 \mathrm{MHz}$, respectively, on a Bruker Avance-II $400 \mathrm{NMR}$ spectrometer using either DMSO- $\mathrm{d}_{6}$ or $\mathrm{D}_{2} \mathrm{O}$ as solvent with tetramethylsilane (TMS) as an internal standard. Mass spectra were obtained on a Waters Q-TOF MICROMA SS LC mass spectrometer. Column chromatography separations were carried out on silica gel (Merck, 60-120 mesh, Mumbai, India). Precoated silica gel plates (Merck, Silica gel 60 F254) were used for analytical thin layer chromatography visualized by exposure to iodine and UV radiations.

\section{Plant material}

The leaves of $\mathrm{AH}$ were collected from Imphal, Manipur during the month of March 2012. It was identified and authenticated by Prof. 
W. Ingo Meitei, Department of Horticulture, Central Agricultural University, Imphal. A voucher specimen (DU/2012/HERB/01) was prepared and the herbarium was deposited at the Department of Pharmaceutical Sciences, Dibrugarh University, Assam, India.

\section{Preparation of extract and isolation of compound}

Plant extraction was carried out by hot extraction process using soxhlet apparatus. Shade-dried leaves were first defatted with petroleum ether. It was then extracted with methanol. The methanol extract was filtered and the solvent was recovered in a rotary evaporator. The residue was collected and further dried in a dessicator. $200 \mathrm{~g}$ of crude methanol extract was subjected to column chromatography using silica gel as the stationary phase using mixtures of ethyl acetate: methanol as the eluting solvent (100:10, 70:30, 50:50, 30:70 and 100:0) to obtain five fractions (F1-F5). A flavonoid compound (white crystal) was obtained and purified from F4. The structure of the active component was identified from the NMR, Mass and IR spectra.

\section{Animals}

Wister rats of either sex, weighing about 150-200 g were obtained from M/S Chakraborty Enterprises, Kolkata. Animal colonies were maintained at the animal house, Department of Pharmaceutical Sciences, Dibrugarh University. They were housed in polypropylene cages during the course of the experimental period and were provided with standard pellet diet (Hindustan Lever, Mumbai, India) and water ad-libitum. The animal experiment was approved by the Institutional Animal Ethics Committee, Dibrugarh University; vide registration number-1576/GO/a/11/CPCSEA dated $17 / 2 / 2012$, and approval number-IAEC/DU/44 dated: 24/9/2013. The animal house was well ventilated and maintained at room temperature $\left(25^{\circ} \mathrm{C} \pm 2\right.$ ${ }^{\circ} \mathrm{C}$ ), $30-35 \%$ of relative humidity and $12 \mathrm{~h}$ dark/light cycles. The place of the experiment was kept hygienic by cleansing with an antiseptic solution, and further procedures involving the care of animals was conducted in conformity with the institutional guidelines.

\section{Acute toxicity study}

Healthy female wister rats were fasted overnight and divided into four groups containing five animals in each group $(n=3)$. They were orally fed with isolated compound dissolved in $0.5 \%$ carboxymethylcellulose (CMC) in increasing dose levels of 50, 100, 800 and $2000 \mathrm{mg} / \mathrm{kg}$. The animals were under observation for $4 \mathrm{~h}$ to see the behavioral changes viz. gross behavior, writhing, convulsion, response to tail pinching, pupil size, itching, excessive salivation, urination, fecal output, water intake, feeding behavior, sedation, neurological and autonomic profiles. After a period of 24 and $72 \mathrm{~h}$, they were observed for any lethality or death and further kept under observation up to $15 \mathrm{~d}$. [11].

\section{Antiulcer activity}

Wister rats were divided into three groups comprising of five animals in each group. Group I (Control) received 0.3\% carboxymethylcellulose (CMC), Group II received standard (Omeprazole) at the dose of $20 \mathrm{mg} / \mathrm{kg}$ body weight. Group III received compound 1 at the dose of $20 \mathrm{mg} / \mathrm{kg}$ for $7 \mathrm{~d}$ consecutively. On the $7^{\text {th }}$ day, ethanol $(1 \mathrm{ml} / 200 \mathrm{~g})$ was administered after $30 \mathrm{~min}$ of drugs administration. $4 \mathrm{~h}$ after ethanol administration, animals were sacrificed by cervical dislocation and stomach was removed. The stomach was cut and opened along the greater curvature and washed with normal saline. The severity of ulcers was observed and measured. The mucosal layer was scrapped and centrifuged with phosphate buffer for biochemical estimation [12]. The percentage protection of ulcer was calculated using the formula

$$
\% \text { Inhibition }=\frac{\text { Ui of control-Ui of test }}{\text { Ui of control }} \times 100
$$

\section{Free acidity and total acidity}

$1 \mathrm{ml}$ of mucosal homogenate was pipette out into a $100 \mathrm{ml}$ conical flask and after adding 3 drops of Topfer's reagent, it was titrated with $0.01 \mathrm{M}$ sodium hydroxide (which was previously standardized with $0.01 \mathrm{M}$ of oxalic acid) until all traces of the red colour disappeared and the colour of the solution was yellowish orange. The volume of alkali added was noted. This volume corresponds to free acidity. Then 2 drops of phenolphthalein solution was added and titration was continued until a definite red tinge reappeared. Again the total volume of alkali added was noted [12]. This volume corresponds to total acidity.

Total Acidity was calculated by using the formula

$$
\text { Total Acidity }=\frac{\text { Volume of NaOH x Actual Normality of NaOH X } 100}{0.1} \mu \mathrm{eq} / \mathrm{ml} / 100 \mathrm{~g}
$$

\section{Estimation of total hexoses}

This was done as per the method of Winzler [13]. To $0.4 \mathrm{ml}$ of the hydrolysate, $3.4 \mathrm{ml}$ of the orcinol reagent was added. The mixture was heated on a boiling water bath for $15 \mathrm{~min}$. This was then taken out, cooled under running tap water and the intensity of the colour was read in a spectronic- 20 absorptiometer at $540 \mathrm{~nm}$ against the blank prepared using distilled water instead of the hydrolysate. The total hexoses content was determined from the standard curve of galactose-mannose and has been expressed as $\mu \mathrm{g} / 100 \mathrm{mg}$ gastric mucosa.

\section{Estimation of hexosamine}

To a volume of $0.5 \mathrm{ml}$ of the hydrolyzed fraction, $0.5 \mathrm{ml}$ of acetylacetone reagent was added. The mixture was heated in boiling water bath for $20 \mathrm{~min}$. After cooling it under tap water, $1.5 \mathrm{ml}$ of $95 \%$ alcohol was added, followed by an addition of $0.5 \mathrm{ml}$ of Ehrlich's reagent. The reaction was allowed for $30 \mathrm{~min}$ and then colour intensity was measured on the spectronic- 20 absorptiometer at $530 \mathrm{~nm}$ against the blank prepared by water instead of the hydro lysate. Hexosamine contents of the samples were determined from the standard curve prepared by using (D+)-glucosamine hydrochloride. The hexosamine content has been expressed as $\mu \mathrm{g} / 100 \mathrm{mg}$ of gastric mucosa [14].

\section{Estimation of fucose}

In a series of three test tubes, one tube contained $0.4 \mathrm{ml}$ of distilled water which served as blank. To the other two tubes, $0.4 \mathrm{ml}$ of the hydrolysates was taken. To all the tubes, added $1.8 \mathrm{ml}$ of sulphuric acid keeping the tubes in an ice-cold water bath to prevent breakage due to the strong exothermic reaction. This mixture was then heated on the boiling water bath for $3 \mathrm{~min}$. The tubes were then taken out and cooled. To the blank and to one of the hydrolysates containing tube, $0.1 \mathrm{ml}$ of cysteine reagent was added while nothing was added to the last tube containing the hydrolysate. After 90 min of reaction, reading was taken in the spectrophotometer at $396 \mathrm{~nm}$ and $430 \mathrm{~nm}$. True optical density for fucose in the hydrolysate was calculated from the differences in the reading obtained at 396 and $430 \mathrm{~nm}$ and subtracting the values without cysteine. This was read against the standard curve prepared with (D+)-fucose. The content of fucose was expressed in terms of $\mu \mathrm{g} / 100 \mathrm{mg}$ of gastric mucosa [15].

\section{Estimation of sialic acid}

To $0.5 \mathrm{ml}$ of the hydrolysate, $0.2 \mathrm{ml}$ of sodium periodate was added and thoroughly mixed by shaking. After $20 \mathrm{~min}, 1 \mathrm{ml}$ of sodium arsenite solution was added to this mixture shaked until disappearance of brown color. Then $3 \mathrm{ml}$ of thiobarbituric acid was added and the mixture was heated in boiling water bath for $15 \mathrm{~min}$. After cooling the tubes, $4.3 \mathrm{ml}$ of cyclohexanone was added and thorough shaking for 15 seconds was done till the entire color was taken up by the cyclohexanone supernatant. The mixture was centrifuged to get a clear pink layer of cyclohexanone. The supernatant was pippeted out and its colour intensity was measured in spectronic-20 absorptiometer at $550 \mathrm{~nm}$. The sialic acid content of the sample was calculated from the standard curve of sialic acid [16]. The sialic acid content was expressed as $\mu \mathrm{g} / \mathrm{ml} \mathrm{mg}$ of gastric mucosa.

\section{Estimation of total protein}

The protein content of the gastric juice was estimated using the method of [17]. A solution (1 ml) was prepared by adding $0.95 \mathrm{ml}$ of water to $0.05 \mathrm{ml}$ of a solution of alcoholic precipitate of gastric juice 
in $0.1 \mathrm{M} \mathrm{NaOH}$. From the $1 \mathrm{ml}$ solution so prepared, $0.4 \mathrm{ml}$ was taken into another test tube. To this $4 \mathrm{ml}$ of alkaline reagent was then added and kept for $10 \mathrm{~min}$. Then $0.4 \mathrm{ml}$ of the phenol reagent was added and $10 \mathrm{~min}$ was allowed for the development of color. Readings were taken against the blank prepared with water at 610 $\mathrm{nm}$ in spectronic-20 absorptiometer. The protein content was calculated from the standard curve prepared with bovine albumin and expressed in terms of $\mu \mathrm{g} / 100 \mathrm{mg}$ of gastric mucosa. The ratio of total carbohydrate (TC) (sum of total hexoses, hexosamine, fucose and sialic acid) to protein (P) was then calculated.

\section{In vivo antioxidant activity}

\section{Superoxide dismutase (SOD)}

SOD was estimated according to the procedure of Oyaizu [18]. To 0.4 $\mathrm{ml}$ of the homogenate, added $1.2 \mathrm{ml}$ of sodium pyrophosphate buffer ( $\mathrm{pH} 8.3$ ), $0.1 \mathrm{ml}$ of $186 \mu \mathrm{M}$ of phenazine methosulphate (PMS), 0.3 $\mathrm{ml}$ of $300 \mu \mathrm{M}$ nitro blue tetrazolium (NBT), $0.2 \mathrm{ml}$ of nicotinamide adenine dinucleotide (NADH) and the volume was made up to $3 \mathrm{ml}$ with distilled water. The reaction was initiated by the addition of $\mathrm{NADH}$. After incubation at $30^{\circ} \mathrm{C}$ for $60 \mathrm{sec}$, the reaction was stopped by the addition of $1.0 \mathrm{ml}$ of glacial acetic acid. The reaction mixture was stirred vigorously and shaken with $4 \mathrm{ml}$ of n-butanol. The mixture was allowed to stand for $10 \mathrm{~min}$, centrifuged and butanol layer was taken out and measured at $560 \mathrm{~nm}$ in a spectrophotometer against butanol. The inhibition of reduction of NBT to blue colored formozan in presence of PMS and NADH was measured at $560 \mathrm{~nm}$ using n-butanol as blank. A sample was prepared without the enzyme which acted as a control. One unit of enzyme activity is defined as enzyme concentration required reducing the optical density at $560 \mathrm{~nm}$ of chromogen protection by $50 \%$ in one min under the assay conditions, and the results have been expressed as $\mu \mathrm{mol} / \mathrm{mg}$ wet tissue.

\section{Glutathione (GSH) activity}

The gastric mucosal scrapping was homogenized in $8 \mathrm{ml}$ of $0.02 \mathrm{M}$ EDTA in a potter elvehjem homogenizer in an ice bath. The homogenate was cooled in an ice bath. Aliquots of $5 \mathrm{ml}$ of homogenates were mixed in $15 \mathrm{ml}$ test tubes with $4 \mathrm{ml}$ of distilled water and $1 \mathrm{ml}$ of $50 \%$ TCA. The tubes were shaken intermittently for $10-15 \mathrm{~min}$ and centrifuged for $15 \mathrm{~min}$ at $3000 \mathrm{rpm} .3 \mathrm{ml}$ of supernatant was mixed and shaken with $4 \mathrm{ml}$ of $0.4 \mathrm{M}$ Tris buffer and $0.1 \mathrm{ml}$ of DTNB and it was shaken. The absorbance was read within 5 min after the addition of DTNB at $412 \mathrm{~nm}$ against a reagent blank with no homogenate. The results were expressed as $\mu \mathrm{mol} / \mathrm{mg}$ wet tissue and were calculated from the standard curve prepared by using standard glutathione [19].

\section{Catalase (CAT) activity}

Gastric mucosal scrapping was homogenized with $0.007 \mathrm{M}$ phosphate buffer at $1-4^{\circ} \mathrm{C}$, centrifuged and the sediment was stirred with cold phosphate buffer. It was allowed to stand in the cold ice bath with occasional shaking. The supernatant was diluted 1:10 with distilled water and $0.04 \mathrm{ml}$ was taken from the mixture. Decomposition of $\mathrm{H}_{2} \mathrm{O}_{2}$ in presence of catalase was measured at 240 $\mathrm{nm}[20]$. Catalase activity was expressed as $\mu \mathrm{mol} / \mathrm{mg}$ wet tissue.

\section{Histopathological study}

After sacrificing the rats by cervical dislocation, stomach was collected, washed in normal saline and fixed by using fixative (picric acid, $40 \%$ formaldehyde and glacial acetic acid) for $24 \mathrm{~h}$ and dehydrated with alcohol. All tissues were cleaned and embedded by using xylene and paraffin (melting point $55-60{ }^{\circ} \mathrm{C}$ ). Tissues were stained by double staining process. To differentiate the nucleus and cytoplasm, haematoxylin (basic dye) and eosin (acid dye) were used. Electron micrographs were performed using transmission electron microscope and photographed were taken by Leica microscope [21].

\section{Statistical analysis}

Results were expressed as mean \pm SEM. Statistical significance was determined by one-way Analysis of Variance (one way ANOVA) followed by Dunnett's ' $t$ ' test with a level of significance set at $p<0.05$.

\section{RESULTS}

\section{Isolation of compound}

A flavonoid compound was isolated from the methanol extract. The spectral data obtained from NMR $\left({ }^{1} \mathrm{H}\right.$ and $\left.{ }^{13} \mathrm{C}\right)$, ESI-MS, FT-IR resulted to the structure of this isolated compound. Compound 1, designated as a flavonoid, was obtained as colourless crystals from ethyl acetate-methanol (30:70) eluents. Its IR spectrum showed characteristic absorption bands for $\mathrm{OH}$ stretching (3254.0), $\mathrm{C}-\mathrm{H}$ stretching, aliphatic- $\mathrm{CH}_{2}$ (2955.7), $-\mathrm{C}=0$ stretching (1705.00), $-\mathrm{OCH}_{3}$ stretching attached to the aromatic ring (1577.86). On the basis of ESI-MS and ${ }^{13} \mathrm{C}$ NMR spectra, its molecular weight was established at $m / z: 452$, consistent with the molecular formula, $\mathrm{C}_{24} \mathrm{H}_{20} \mathrm{O}_{9}$. It indicated ten double bond equivalents; five of them were adjusted in the flavonoid nucleus with one carbonyl function. Other five double bonds are in phenyl and furan groups attached with flavonoid nucleus. The ${ }^{1} \mathrm{H}$ NMR spectrum of Compound 1 exhibited five oneproton singlet signals at between $\delta 3.84$ to 3.90 that assigned to five hydroxyl groups present in the structure. The presence of several signals between $86.90-7.07$ supported to a flavonoid in the structure. The ${ }^{13} \mathrm{C}$ NMR spectrum of Compound 1 displayed signals for carbonyl carbon at $\delta 24.418$ and several double bonded carbons at $\delta 19.397,20.841,24.109,25.210,29.029,29.602,35.824,36.288$, $39.726,50.429,53.330,55.959,58.060,58.507,129.075,129.323$, 174.067, and 174.167. On the basis of the foregoing account, the structure of Compound 1 has been elucidated as 3, 5, 6-trihydroxy2-(4-hydroxy-3-(6-hydroxy-4, 5, 6, 7-tetrahydro benzofuran-7-yl) phenyl-7-methoxy-4H-chromen-4-one. This is a new flavonoid isolated from plant sources.

Compound 1: 3, 5, 6-trihydroxy-2-(4-hydroxy-3-(6-hydroxy-4, 5, 6, 7tetrahydrobenzofuran-7-yl) phenyl-7-methoxy-4H-chromen-4-one<smiles></smiles>

FTIR spectrum $\left(\nu_{\max }\right.$ in $\mathrm{cm}^{-1}$, Film): $3254.0(\mathrm{OH}$ stretching), 2955.7 ($\mathrm{CH}_{3}$ stretching), 2874.07 ( $-\mathrm{O}-\mathrm{CH}_{3}$ stretching), 1705.00 ( $\mathrm{C}=0$ stretching), $1577.86\left(-\mathrm{OCH}_{3}\right.$ stretching attached to aromatic ring), 1512.09 (=C-H bending, aromatic), 1401.76 (-OH deformation), 1354.45 (C-O stretching,-OH attachment), 1130.00-1037.87(C-O-C stretching).

Mass spectrum (TOF MS, $m / z$ ): $452[\mathrm{M}+1]$ for $\mathrm{C}_{24} \mathrm{H}_{20} \mathrm{O}_{9}$

\section{Antiulcer study}

In the present study, Compound 1 was evaluated for its potential as an antiulcer agent against ethanol-induced ulcer. The ulcer was induced by oral administration of ethanol. Ethanol-treated animals showed a high severity index. Compound 1 and the standard drug (Omeprazole) significantly reduced the severity of ulceration in the mucosa of the rats (fig. 1). Compound 1 showed a significant $(p<0.01)$ reduction in ulcer index thereby increasing the percentage protection (table 1) and reduced the content of free acid in the mucosal content; either tended to individual carbohydrates or total carbohydrates and also increased the total protein content (table 2). Ethanol significantly decreased the SOD and GSH levels and increased CAT levels in the rat mucosal scrapings.

However, treatment with Compound 1 increased the levels of SOD and GSH and decreased in CAT levels (table 3). Histopathological studies were carried out on the rat stomach. After seven days of treatment, the rats treated with ethanol showed loss of gland textures with the erosion of the epithelial layer, edema and haemorrhage of the stomach wall. Compound 1 treated animal showed no ulceration in gastric mucosa which is similar to the normal texture (fig. 2). 
Table 1: ${ }^{1} \mathrm{H}$ and ${ }^{13} \mathrm{C}$ NMR spectral data of compound 1

\begin{tabular}{|c|c|c|}
\hline Position No. & $\delta_{H}$ & $\delta c$ \\
\hline 1 & - & - \\
\hline 2 & & 36.28 \\
\hline 3 & & 35.82 \\
\hline 4 & & 29.60 \\
\hline 5 & & 24.10 \\
\hline 6 & & 29.02 \\
\hline 7 & & 20.84 \\
\hline 8 & $6.94(\mathrm{~d}, 1 \mathrm{H}, \mathrm{J}=14)$ & 29.02 \\
\hline $1^{\prime}$ & & 39.72 \\
\hline $2^{\prime}$ & $7.07(\mathrm{~d}, 1 \mathrm{H}, \mathrm{J}=8)$ & 50.42 \\
\hline $3^{\prime}$ & & 53.33 \\
\hline $4^{\prime}$ & & 55.95 \\
\hline $5^{\prime}$ & & 58.06 \\
\hline $6^{\prime}$ & & 58.50 \\
\hline $1 "$ & & - \\
\hline $2 "$ & $4.01(\mathrm{~d}, 1 \mathrm{H}, \mathrm{J}=2)$ & 174.06 \\
\hline $3 "$ & $4.04(\mathrm{~d}, 1 \mathrm{H}, \mathrm{J}=2)$ & 174.16 \\
\hline $4 "$ & & 127.65 \\
\hline $5 "$ & $3.90(\mathrm{t}, 2 \mathrm{H}, \mathrm{J}=11.6)$ & 65.82 \\
\hline 6" & $3.81(\mathrm{~m}, 2 \mathrm{H})$ & 60.28 \\
\hline $7^{\prime \prime}$ & & $59.44 \mathrm{~s}$ \\
\hline \multicolumn{3}{|l|}{$=0$} \\
\hline$-\mathrm{OH}$ & $3.84(\mathrm{~s}, 1 \mathrm{H})$ & \\
\hline$-\mathrm{OH}$ & $3.86(\mathrm{~s}, 1 \mathrm{H})$ & \\
\hline$-\mathrm{OH}$ & $3.88(\mathrm{~s}, 1 \mathrm{H})$ & \\
\hline$-\mathrm{OH}$ & $3.90(\mathrm{~s}, 1 \mathrm{H})$ & \\
\hline$-\mathrm{OCH}_{3}$ & $3.30(\mathrm{~s}, 3 \mathrm{H})$ & \\
\hline
\end{tabular}

Table 1: Effect of isolated compounds on Ethanol-induced ulcer rats indicating ulcer index and percentage protection

\begin{tabular}{lll}
\hline Groups & Ulcer index $\left(\mathrm{U}_{\mathrm{i}}\right)$ & Percentage protection \\
\hline I & $16.60 \pm 2.37^{\mathrm{b}}$ & - \\
II & $2.60 \pm 0.18^{\mathrm{a}}$ & 89.12 \\
III & $4.60 \pm 0.29^{\mathrm{a}, \mathrm{b}}$ & 80.75 \\
\hline
\end{tabular}

Data represents mean \pm SEM $(\mathrm{n}=5) . \mathrm{a}={ }^{* *} \mathrm{p}<0.01$ compared to normal control, $\mathrm{b}={ }^{* *} \mathrm{p}<0.01$ compared to standard control.
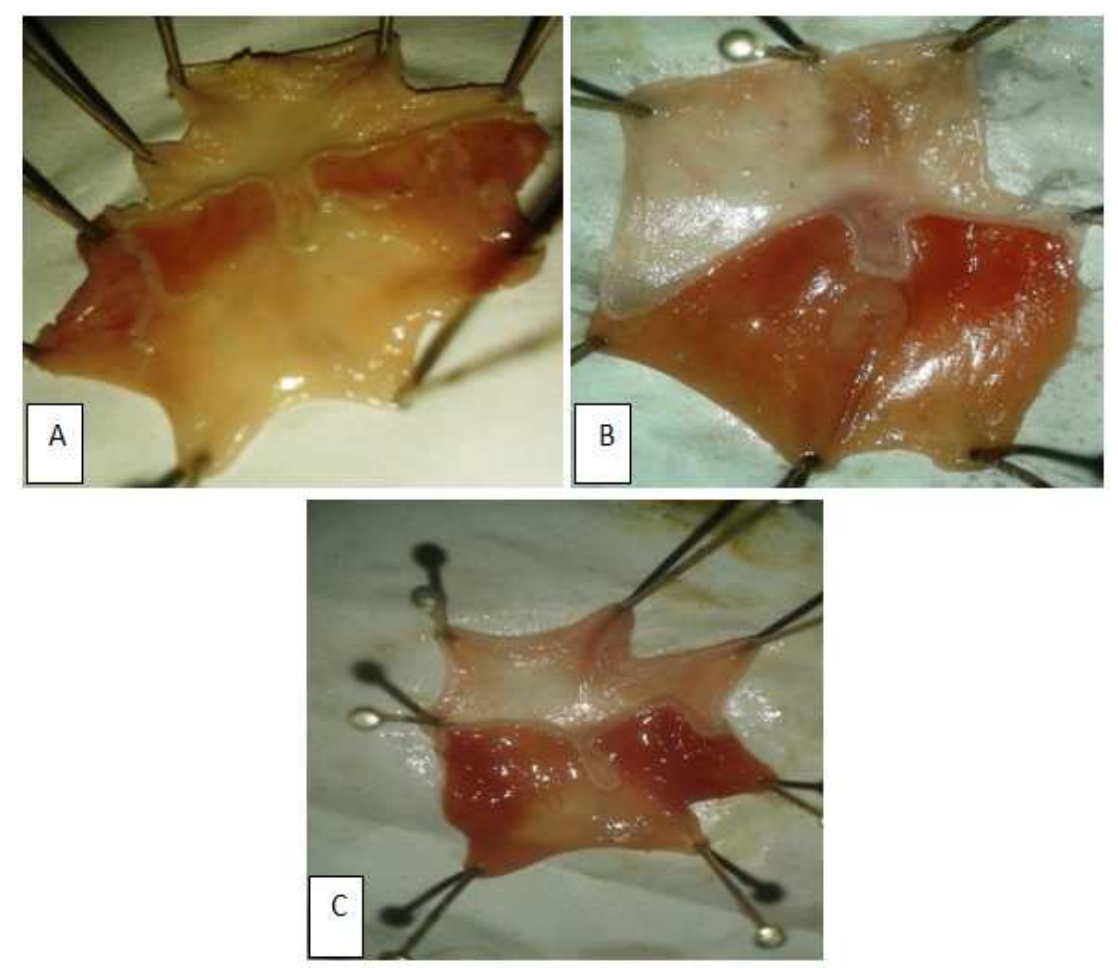

Fig. 1: (A) Group I: Perforation and erosion of mucous layer (B) Group II: restoration to normal mucous layer (C) Group III: Mild inflammation on the mucous layer 
Table 2: Effect of isolated compounds on mucosal scrapings of ethanol-induced ulcer rats

\begin{tabular}{|c|c|c|c|}
\hline Gastric content & Group I & Group II & Group III \\
\hline Free acidity $(\mu \mathrm{eq} / \mathrm{ml}$ & $83.44 \pm 0.98^{b}$ & $38.98 \pm 0.39 a$ & $44.10 \pm 0.53^{\mathrm{a}, \mathrm{b}}$ \\
\hline Total acidity $(\mu \mathrm{eq} / \mathrm{ml})$ & $102.56 \pm 0.89 b$ & $60.53 \pm 0.58^{a}$ & $65.14 \pm 1.63^{\mathrm{a}, \mathrm{b}}$ \\
\hline Total Hexoses(A) & $10.65 \pm 0.52$ & $59.08 \pm 0.84^{a}$ & $52.46 \pm 1.44^{\mathrm{a}}$ \\
\hline Hexosamine (B) & $10.02 \pm 0.23$ & $38.10 \pm 1.02^{\mathrm{a}}$ & $35.43 \pm 1.37^{a}$ \\
\hline Fucose $(C)$ & $8.50 \pm 0.24$ & $54.03 \pm 0.33^{\mathrm{a}}$ & $48.38 \pm 1.01^{\mathrm{a}}$ \\
\hline Sialic acid (D) & $11.06 \pm 0.70$ & $27.64 \pm 3.88^{a}$ & $21.67 \pm 1.30^{\mathrm{a}}$ \\
\hline $\mathrm{TC}(\mathrm{A}+\mathrm{B}+\mathrm{C}+\mathrm{D})$ & $10.05 \pm 0.56^{b}$ & $44.71 \pm 7.23^{a}$ & $39.48 \pm 6.96^{a}$ \\
\hline Total Protein & $6.93 \pm 0.38$ & $29.69 \pm 0.53^{a}$ & $28.80 \pm 1.25^{\mathrm{a}}$ \\
\hline
\end{tabular}

Data represents mean \pm SEM $(n=5) . a={ }^{* *} \mathrm{p}<0.01$ compared to normal control, $\mathrm{b}={ }^{* *} \mathrm{p}<0.01$ compared to standard control

Table 3: In vivo antioxidant activity of the isolated compounds

\begin{tabular}{llll}
\hline Groups & SOD $(\boldsymbol{\mu m o l} / \mathbf{m g}$ wet tissue) & GSH $(\boldsymbol{\mu m o l} / \mathbf{m g}$ wet tissue) & CAT $(\boldsymbol{\mu m o l} / \mathbf{m g}$ wet tissue) \\
\hline I & $14.72 \pm 0.18^{\mathrm{b}}$ & $1.74 \pm 0.08^{\mathrm{b}}$ & $70.91 \pm 0.25^{\mathrm{b}}$ \\
II & $40.56 \pm 0.08^{\mathrm{a}}$ & $4.52 \pm 0.04^{\mathrm{a}}$ & $45.80 \pm 0.08^{\mathrm{a}}$ \\
III & $38.57 \pm 0.10^{\mathrm{a}, \mathrm{b}}$ & $4.05 \pm 0.02^{\mathrm{a}, \mathrm{c}}$ & $47.97 \pm 0.26^{\mathrm{a}, \mathrm{b}}$ \\
\hline
\end{tabular}

Data represents mean \pm SEM $(n=5) . a={ }^{* *} \mathrm{p}<0.01$ compared to normal control, $\mathrm{b}={ }^{* *} \mathrm{p}<0.01$ compared to standard control, $\mathrm{c}={ }^{*} \mathrm{p}<0.05$ compared to standard control

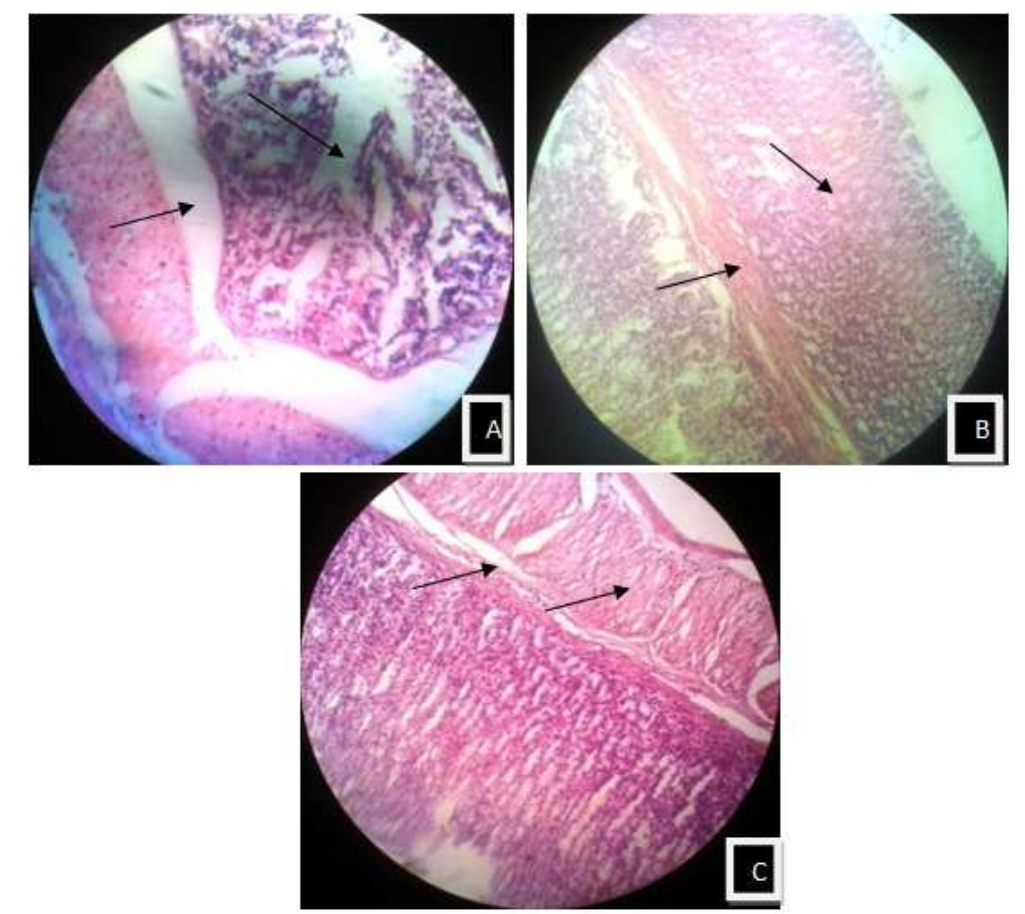

Fig. 2: Histopathology of the stomachs in ethanol-induced ulcer (A) Group I: Loss of gland textures with erosion of the epithelial layer, edema and hemorrhage of the stomach wall (B) Group II: Restored the gland texture with no ulceration in the gastric mucosa (C) Group III: Restored gland textures but mild inflammation

\section{DISCUSSION}

The gastric mucosa is exposed to several noxious substances of endogenous (acid, pepsin, bile) and exogenous (alcohol, NSAIDS) origin. Ulcer starts when the mucosal integrity of the defence system is lower than that of the exogenous system. To maintain this system in equilibrium, different types of therapeutic agents (natural, antibiotics, synthetic) are used to inhibit the gastric acid secretion, to heal the affected part or to encourage the mucosal defence mechanisms by increasing the production of mucous [30]. Gastric ulceration produced by ethanol is multifactorial. Ethanol can rapidly penetrate into the gastric mucosa and increased the mucosal permeability, leading to the release of vasoactive factors causing vascular damage and gastric injury $[31,32]$. Another factor of gastric injury is the high production of free radicals in the stomach due to lipid peroxidation resulting to cell damage. Mucosal damage may be also due to the increased of neutrophil free radicals and proteases. A rapid and convenient way of screening antiulcer drugs is the ethanol-induced model. Compound 1 showed a protective effect of the mucosal layer because of the depletion of free radicals in the mucosa produced by ethanol. Various mechanisms enhanced the secretion of mucus bicarbonate production, inhibition of gastric secretion and neutralization. Measurement and analysis of gastric content is one of the important factors in gastric ulcer diagnosis. The easy availability of free radicals in the mucosal layer helps in the formation of acids and resulting to acidity. A number of mechanisms include the increased in the secretion of mucous bicarbonates, prostaglandins, reducing gastric secretion or neutralizing the gastric acidity. Compound 1 reduced the free and total acidity of the gastric content by increased in the secretion of bicarbonates and mucin 
content and hence proving its antisecretory action (table 2). It also showed the antioxidant effect in the ethanol-induced animals by increasing the levels of the SOD and GSH levels with the decreased of CAT levels which were disarranged by ethanol. Decrease of antioxidant status leads to oxidative stress in ulcer resulting deleterious effects of free radicals. SOD and GSH are the major enzymes that scavenged and remove free radicals in vivo. With the decreased of these antioxidants, the production of superoxide and hydrogen peroxide anion is high in a biological system and it may result in generating the hydroxyl radicals and initiation of lipid peroxidation. From the result, the new flavonoid compound proved its antioxidant activity by increasing the levels of SOD and GSH.

Ethanol in rat mucosa produced endothelial microvascular damage; mucosal lesions and hemorrhage. These are attributed to the inhibition of prostaglandin production by cyclo-oxygenase resulting in overproduction of leukotrienes via. 5-lipoxygenase pathway [33]. These agents provoke the permeability of $\mathrm{Na}^{+}$and $\mathrm{H}^{+}$ions in the mucosal layer, producing mucosal erosions and damage of the cell membrane. The Compound 1 significantly reduced the mucosal cell damage, increase in bicarbonate content and proving an increase of prostaglandin synthesis [34].

Allium hookeri, not only a traditional food condiment but also used as a medicine in the traditional medication system. AH has been reported in the preservation of pork meat and bread for a long time $[35,36]$. This indicates that, AH can also be used as a preservative in the conservation of cooked foods.

\section{CONCLUSION}

The present study proves that the isolated flavonoid is effective against ethanol-induced ulcer. Compound 1 might have the potential to increase the prostaglandin production and mucin in the stomach. Further study may be carried out to find out the actual mechanism of action.

\section{ACKNOWLEDGEMENT}

The authors are grateful to the Department of Pharmaceutical Sciences, Dibrugarh University for providing the laboratory facilities.

\section{AUTHORS CONTRIBUTIONS}

The experimental work was done by Khumanthem Deepak Singh under the supervision of Prof. Dipak Chetia. Dr. Biplab De helped in the structure elucidation of the isolated compound.

\section{CONFLICT OF INTERESTS}

Authors do not have any conflict of interest

\section{REFERENCES}

1. Tripathi KD. Essentials of medical pharmacology. $6^{\text {th }}$ ed. Jaypee Brothers, New Delhi; 2008.

2. Berardi RR, Welage S. Peptic ulcer disease. In: Dipiro TJ, RL Talbert, G Yes, G Matzke, G Wells, M Posey. Editors. Pharmacotherapy: A Pathophysiologic Approach. $6^{\text {th }}$ ed. McGraw-Hill; 2005.

3. Suerbaum S, Michetti S. Helicobacter pylori infection. N Engl J Med 2002;347:1175-86.

4. Clouatre D, Rosenbaum M. The diet and benefits of HCA. Keats Publishing, New York; 1994.

5. Kalaichelvi K, Sharmila S, Dhivya SM. In vitro antioxidant and antiulcerogenic activity of Cayratia pedata var. glabra against experimentally induced gastric lesions in wistar strain albino rats. Asian J Pharm Clin Res 2018;11:105-10.

6. Ayam VS. Allium hookeri Thw. Enum. A lesser-known terrestrial perennial herb used as food and its ethnobotanical relevance in Manipur. Afr J Food Agric Nutr Dev 2011;11:5389-412.

7. Sukumar S. The economic plants of Manipur and their uses. Career publications, Imphal; 2009.

8. Singh KB, Singh NM. Antioxidant and free radical scavenging potential of Allium hookeri thwaites roots extract studied using in vitro models. J Adv Biol 2014;4:275-85.

9. Singh KD, Chetia D, Junejo JA. Antiulcer and in vitro antioxidant activity of Allium hookerii: an ethnomedicinal plant of Manipur. Asian J Pharma Clin Res 2015;8:137-42.
10. Singh KD, Chetia D, Mazumdar S. Antidiabetic activity of methanolic extract of Allium hookerii leaves. Indo Am J Pharm Res 2013;3:4098-104.

11. http://www.oecd-ilibrary.org/docserver/ [Last accessed on 10 Nov 2017]

12. Hollander D, Tarnawski A, Krause WJ, Gergely H. Protective effect of sucralfate against alcohol-induced gastric mucosal injury in the rat. Gastroenterology 1985;88:366-74.

13. Winzler RJ. Determination of serum glycoproteins. Methods Biochem Anal 1955;2:279-311.

14. Dische Z, Borenfreund E. A spectrophotometric method for the micro determination of hexosamines. J Biochem 1950;184:517-22.

15. Dische Z, Schettles LB. A specific colour reaction for methyl pentoses and spectrophotometric micro method for determination. J Biochem 1948;175:595-603.

16. Warren L. The thiobarbituric acid assay of sialic acids. J Biol Chem 1959;234:1971-5.

17. Lowry OH, Rosenborough NI, Farr AL, Randall RJ. Protein measurement with folin phenol reagent. J Biol Chem 1951;193:265-75.

18. Oyaizu M. Studies on products of browning reaction: Antioxidative activities of products of browning reaction prepared from glucosamine. Japanese J Nutr 1986;44:307-15.

19. Sadhu SK, Okuyama E, Fujimoto H, Ishibashi M. Separation of Leucas aspera, a medicinal plant of Bangladesh, guided by prostaglandin inhibitory and antioxidant activities. Chem Pharm Bull 2003;51:595-8.

20. Luck H. Catalase. In: Methods of enzymatic analysis. Edited by Bergmeyar HU, Verlag Chemie. Academic Press: New York; 1963.

21. Kehar U, Wahi PN. Cytologic and histologic behaviour patterns of the premalignant lesions of the cervix in experimentally induced cervical dysplasia. Acta Cytologica 1967;11:1-15.

22. Halliwell B. Use of desferrioxamine as a 'probe' for the irondependent formation of hydroxyl radicals. Evidence for a direct reaction between desferal and the superoxide radical. Biochem Pharmacol 1985;34:229-33.

23. Wang SY, Kuo YH, Chang HN, Kang PL, Tsay HS, Lin KF, et al. Profiling and characterization antioxidant activities in Anoectochilus formosanus hayata. J Agric Food Chem 2002;50:1859-65.

24. Hyland K, Voisin E, Banoun H, Auclair C. Superoxide dismutase assay using alkaline dimethylsulfoxide as superoxide aniongenerating system. Anal Biochem 1983;135:280-7.

25. Kakkar P, Das B, Viswanathan PN. A modified spectrophotometric assay of superoxide dismutase. Indian J Biochem Biophys 1984;21:130-2.

26. Alam MN, Bristi NJ, Rafiquzzaman M. Review on in vivo and in vitro methods evaluation of antioxidant activity. Saudi Pharmaceutical J 2013;21:143-52.

27. Ruch RJ, Cheng SJ, Klaunig JE. Prevention of cytotoxicity and inhibition of intercellular communication by antioxidant catechins isolated from Chinese green tea. Carcinogenesis 1989;10:1003-8.

28. Sedlak J, Lindsay RH. Estimation of total, protein-bound and non-protein sulfhydryl groups in tissue with Ellman's reagent. Anal Biochem 1968;25:192-205.

29. Halliwell B, Guttiredge JM. Free radicals biology and medicine. Oxford: Clarendon Press; 1989.

30. Piper DW, Stiel DD. Pathogenesis of chronic peptic ulcer, current thinking and clinical implications. Med Prog 1986;2:7-10.

31. Zubaida Y, Ying W, Elias B. Phytochemistry and pharmacological studies on Solanum torvum Swartz. J Appl Pharm Sci 2013;3:152-60.

32. Narayan S, Devi RS, Jainu M, Sabitha KE, Devi CSS. Protective effect of the polyherbal drug, ambrex in the ethanol-induced gastric mucosal lesion in experimental rats. Indian J Pharmacol 2004;36:34-7.

33. Nasuti C, Gabbianelli R, Falcioni G, Cantalamessa F. Antioxidant and gastroprotective activities of anti-inflammatory formulations derived from chestnut honey in rats. Nutr Res 2006;26:130-7.

34. Rainsford KD. Gastric ulcerogenecity of non-steroidal antiinflammatory drugs in mice with mucosa sensitized by cholinomimetic treatment. J Pharm Pharmacol 1978;39:669-72. 
35. Eun YS, Chang WP, Go EH, Ki WL, Chi HL. Effect of addition of Allium hookeri on the quality of fermented sausage with meat from sulfur fed pigs during ripening. Korean J Food Sci 2014;34:263-72.
36. Hee JL, Jae EB, Nami J. Quality characteristics and storage stability of bread with Allium hookeri powder. Korean J Food Nutr 2014;27:318-29. 